Article

\title{
Climate Change and Alpine Screes: No Future for Glacial Relict Papaver occidentale (Papaveraceae) in Western Prealps
}

\author{
Yann Fragnière ${ }^{1}$, Loïc Pittet ${ }^{1}$, Benoît Clément ${ }^{1}$, Sébastien Bétrisey ${ }^{1}$, Emanuel Gerber ${ }^{2}$, \\ Michał Ronikier ${ }^{3}$ (D), Christian Parisod ${ }^{4}$ (D) and Gregor Kozlowski ${ }^{1,2,5, *(D)}$ \\ 1 Department of Biology and Botanic Garden, University of Fribourg, Chemin du Musée 10, \\ CH-1700 Fribourg, Switzerland; yann.fragniere@unifr.ch (Y.F.); loic.pittet@unifr.ch (L.P.); \\ benoit.clement@unifr.ch (B.C.); sebastien.betrisey@unifr.ch (S.B.) \\ 2 Natural History Museum Fribourg, Chemin du Musée 6, CH-1700 Fribourg, Switzerland; \\ emanuel.gerber@fr.ch \\ 3 W. Szafer Institute of Botany, Polish Academy of Sciences, Lubicz 46, PL-31-512 Krakow, Poland; \\ m.ronikier@botany.pl \\ 4 Institute of Plant Sciences, University of Bern, Altenbergrain 21, CH-3013 Bern, Switzerland; \\ christian.parisod@ips.unibe.ch \\ 5 Plant Systematics and Evolutionary Biology, Shanghai Chenshan Plant Science Research Center, \\ Chinese Academy of Sciences, Shanghai 201602, China \\ * Correspondence: gregor.kozlowski@unifr.ch
}

Received: 31 July 2020; Accepted: 1 September 2020; Published: 7 September 2020

\begin{abstract}
Glacial relicts, especially those with very narrow habitat requirements, are particularly affected by global warming. We considered Papaver occidentale, a glacial relict endemic to the Western Prealps, belonging to the alpine poppy complex (P. alpinum aggr.), as a model taxon to study the actual status and potential future distribution of species restricted to particular microrefugia. For this study, all known localities were visited, each population was georeferenced and the number of individuals was estimated. Species Distribution Modelling (SDM) was used to evaluate the present and future potential distribution range and habitat suitability, taking into account the specificity of its habitat (calcareous screes). According to our study, there are globally 19 natural populations of P. occidentale, and a total of about 30,000 individuals. The taxon is a highly specialized alpine plant growing in the majority of natural sites between 1900 and $2100 \mathrm{~m}$ a.s.l. on north-facing screes. Predictions for the end of the 21st century indicate that a suitable area will significantly decrease $(0-30 \%$ remaining). Under the most severe climatic scenarios (RCP 8.5), the species risks complete extinction. The long-term in situ conservation of P. occidentale, and all other taxa of the P. alpinum complex, is unlikely to be achieved without slowing global climate change. More generally, our fine-scale study shows that local environmental buffering of large-scale climate change in high-mountain flora may be very limited in specialised taxa of patchy environments such as screes.
\end{abstract}

Keywords: arctic-alpine flora; climate change; extinction risk; microrefugia; narrow endemism; Papaver alpinum aggr.; screes; species distribution modelling

\section{Introduction}

Understanding how species respond to climate change is a major challenge of conservation biology [1]. This is especially the case for high mountain plants, and more specifically glacial relicts inhabiting European Alps [2-4]. Relicts are remnants of past populations that have become fragmented by climate-driven changes and habitat loss [5]. These remnants were left behind during past range 
shifts and can persist today only in enclaves with suitable environmental conditions in areas with inhospitable regional climates [6]. The Alps, along with the neighboring mountain ranges, played an important role in forming the biogeographical patterns in Europe and acted as a refugium for many taxa throughout several ice age cycles [7-12]. During recent decades, the glacial and postglacial histories of arctic-alpine plant species have been extensively investigated [13-18]. However, many relict taxa of the alpine region still await thorough analysis as only a few punctual studies have explored the conservation status of the glacial relicts in Europe $[19,20]$. Similarly, although glacial relicts are expected to respond dramatically to climate warming, very few studies exist on their reaction to global warming in their current microrefugia [1,21].

In our study, we investigated a typical glacial relict Papaver occidentale (Markgr.) H.E. Hess et al. (Papaveraceae) (Figure 1). The species is a narrow endemic of the Western Prealps, growing in the alpine zone in plant associations typical of calcareous screes (Thlaspion rotundifolii) [22-25]. Papaver occidentale belongs to the monophyletic section Meconella including ca. 50 poppy species, that have mainly circumpolar arctic distribution with some geographically isolated species distributed in the alpine zone of temperate regions [26,27]. This group hosts some of the most northerly-growing plants in the world, like Papaver radicatum, which grows at latitudes up to $83^{\circ}$ North $[28,29]$. More specifically, P. occidentale belongs to the alpine poppy complex Papaver alpinum s.1., which is distributed in small isolated regions all across the Alps and neighbouring mountain ranges [24,30,31]. Because of the highly polymorphic character of P. alpinum complex, its taxonomic division is not fully resolved [31], it illustrates perfectly the complicated evolutionary and biogeographic history of the Alps. Nevertheless, it was demonstrated that $P$. occidentale forms a natural and probably monophyletic group with three other white-flowered and narrow-lobed alpine poppies, that are confined to calcareous bedrocks: P. alpinum s.str., P. sendtneri (both north-eastern Alps), and P. tatricum (Tatra mountains in the Carpathians) [30-34]. The recolonization history of the Prealps by this taxon after the Last Glacial Maximum (about 20 kya $\mathrm{BP}$ ) was complex and the present genetic structure of $P$. occidentale is likely a result of a mixture of local survival and immigration [34]. Despite its priority status in many regions of Switzerland and France [35] and its symbolic value to some regions [36], the plant was never studied across its entire distribution area. Thus, besides very few local and technical reports [37-39], many aspects of its biology and biogeography (e.g., chorology, sensitivity to global change) have not been studied at all.

Papaver occidentale grows exclusively on steep screes and in inaccessible summit parts of the alpine zone [36]. Thus, its habitat is usually not disturbed by any direct human activity (Figure 1). However, the plant is perennial and stenothermic, making it vulnerable to climate change [38]. Species Distribution Modelling (SDM) combines species' current natural occurrence data and environmental variables to estimate the geographic range of suitable habitats in the past, present, and future [40-43]. It has been widely applied in conservation biology to predict potential shifts in geographic ranges in response to climate changes, e.g., [44]. However, the predictions and use of SDM for alpine plants are challenging due to a complex topographic and edaphic pattern of the high-altitude areas [45]. This is even more the case for plants inhabiting very specific alpine habitats, such as calcareous screes, which is the case of P. occidentale.

The present study aims at answering the following questions: (1) What is the present global distribution of Papaver occidentale? (2) What are the population sizes in different regions across its distribution area? (3) What are the ecological preferences of the species? Furthermore, we aimed at applying Species Distribution Modelling (SDM) based on the collected occurrence data, to (4) evaluate the present potential distribution range, and (5) predict the location of suitable habitats of $P$. occidentale in the future, considering not only various climate change scenarios but also its unique habitat specificity. Finally, based on our findings, we discuss the conservation implications of our results for the model taxon as well as for other relict plants, especially those highly specialized for alpine screes. 

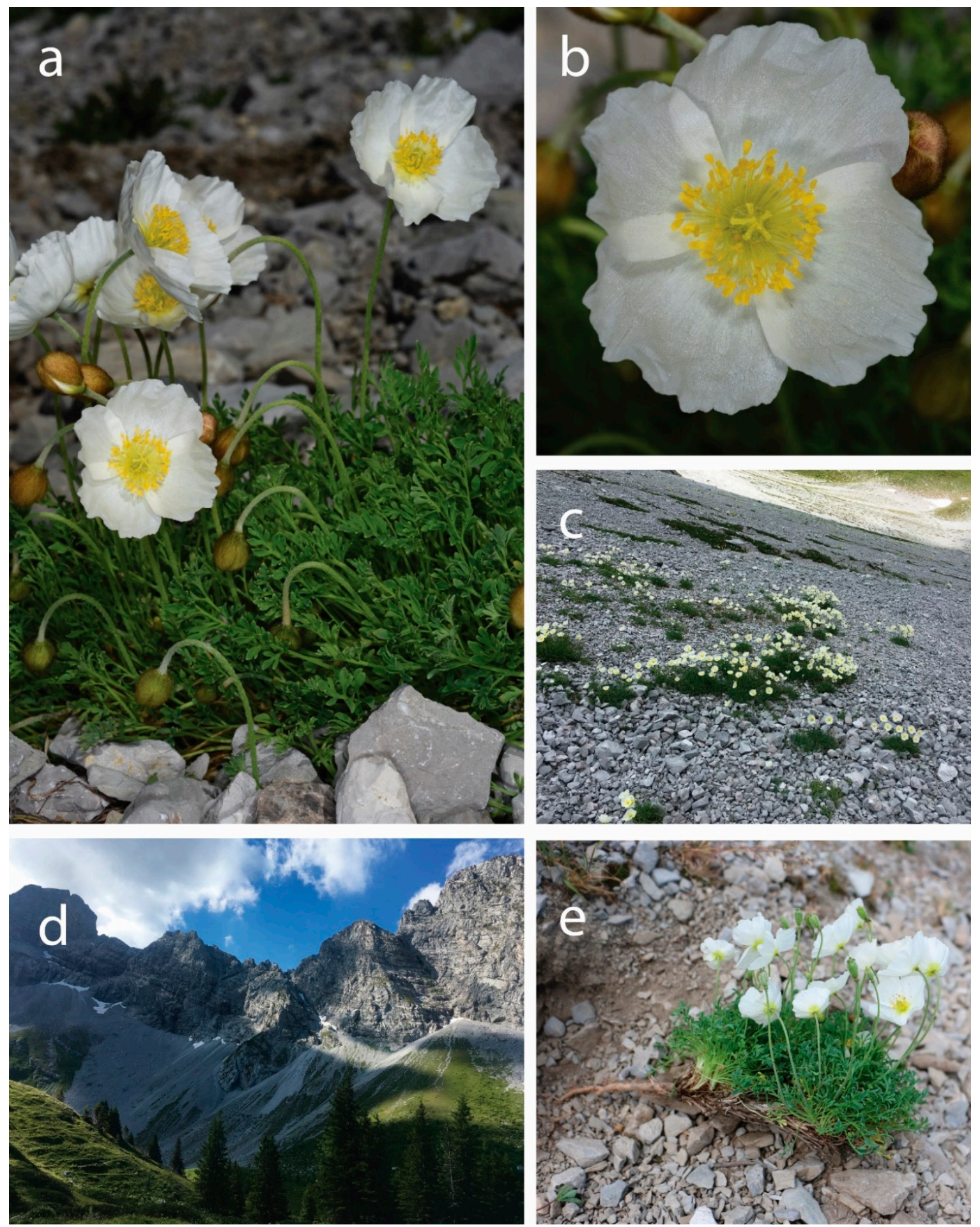

Figure 1. Papaver occidentale. (a) individual plant forming numerous flowers; (b) close up of the flower; (c) typical population growing in calcareous scree (Spillgerte, canton of Bern); (d) typical habitat, north-facing screes and summits (Spillgerte, canton of Bern); (e) each tuft is formed by one individual, anchored in the mobile scree with one large and long pivotal root. Plants reproduce exclusively sexually (no vegetative reproduction) and reach the maximum age of ca. 8 years. 


\section{Materials and Methods}

\subsection{Study Area and Data Collection}

The studied area covered the whole distribution of Papaver occidentale, namely the Western Prealps between Switzerland and France. Information about all known locations of P. occidentale was obtained from Info Flora (www.infoflora.ch), as well as elucidated from the literature [32,36], from the unpublished reports [38,39], and from personal communications of local experts (B. Clément from the Botanical Garden of the University of Fribourg and D. Jordan from France). The populations from the Swiss canton of Lucerne were identified as belonging to P. sendtneri [34] and were not taken into consideration in the present study.

All populations of $P$. occidentale were visited and investigated between July and September 2018 (Figures 1 and 2, Table S1, Supplementary Materials). The location of each population was georeferenced directly using field GPS receivers. The number of individuals was estimated as follows: for large populations (>100 individuals), several GPS locations were recorded (10 to $50 \mathrm{~m}$ distance between points) with each time the estimation of the number of individuals (direct counting or, when the plants are too dense, counting on a small area with an extrapolation). For small populations ( $<100$ individuals) one GPS location was measured and all individuals counted. Because of the field characteristics (moving screes), it was not possible to use a standard procedure (like a grid pattern) to collect the data. The proximity of high cliffs and strong slopes could have decreased the GPS precision, so all GPS locations were checked afterward on a GIS software with orthophotos, and corrected if necessary (final horizontal error $<20 \mathrm{~m}$ ). For SDM, every single individual is considered as an occurrence (presence points, the methodology described in Table S2, Supplementary Materials).

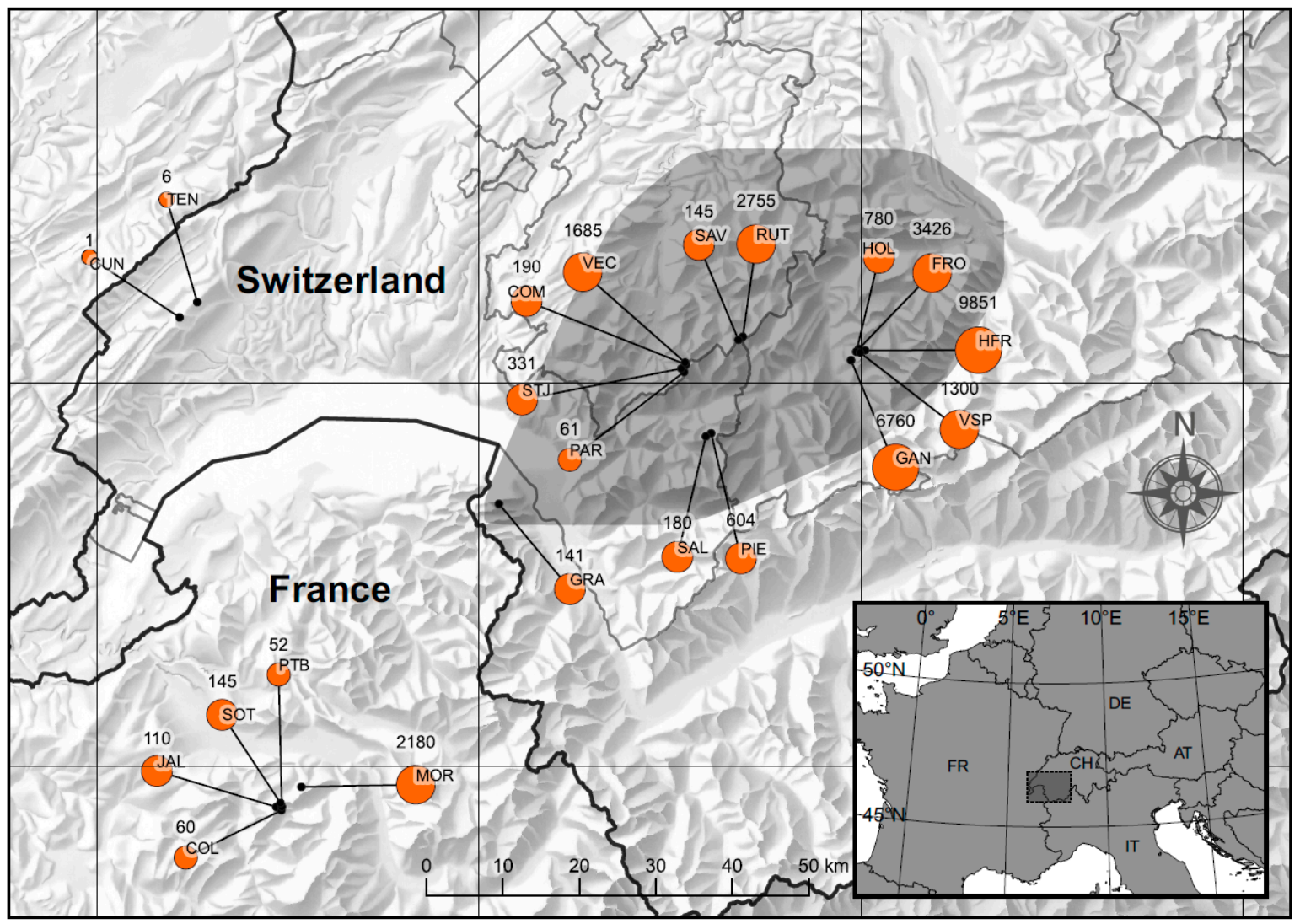

Figure 2. Location of the 21 populations of Papaver occidentale, with their corresponding name (acronyms) and number of individuals (size of dots reflect the population size). The shaded zone indicates the area considered for Species Distribution Modelling (SDM). 


\subsection{Environmental Variables}

The statistical analyses and species distribution modelling (SDM) was conducted in the Swiss Western Prealps, from the Lake of Geneva to the Lake of Thun (the centre of P. occidentale distribution). Populations in France were excluded because it was not possible to have access to the environmental variables with the same resolution and homogeneity as those of Switzerland.

We selected a set of 14 environmental variables, which are likely to play a role in P. occidentale distribution (Table 1). The most highly reliable data for the studied area, with the finest available resolution, were used. These data were gathered from different sources. The resolution of the environmental variables used for the SDM was $10 \mathrm{~m}$ (Table 1).

Climatic and topographic variables are the basis of SDM, but soil or geology plays also an essential role, mainly for plants [46]. As P. occidentale is exclusively linked to moving calcareous screes, this azonal factor plays an essential role to model its distribution. As no exhaustive data exist, we developed this layer ourselves, by delimiting area mainly using orthophotos and in-field knowledge.

The variable EASTNESS (west-east slope aspect) was excluded as it was assumed as not relevant and biased as the mountain chains are mainly oriented from SW to NE in the studied area (on clockwise direction).

The variable ELEVATION was not used in the model because it is an indirect variable [42,47]. It was substituted by the temperature (TEMP), which is a direct variable and more suitable to make predictions with future climatic scenarios. The original data for temperature ( $1 \mathrm{~km}$ resolution) was highly correlated with ELEVATION (R-squared value $=0.92, p$-value $<0.001$ ). TEMP was thus calculated as a function of ELEVATION, to downscale the resolution to $10 \mathrm{~m}$.

We checked for multicollinearity problems between variables, which is assumed as an important source of model uncertainty. It is safer to avoid selecting highly correlated variables for SDM [47-50]. The variance inflation factor (VIF) was calculated and we looked at paired correlation plots and r-squared values (Table S2 [47,51-53]). With the retained variables, all VIF scores were under 5, (recommendation for value below 10, [47]) and paired correlation R-squared values did not exceed 0.6 (Figures S1-S3, Supplementary Materials), which is below an acceptable threshold of 0.8 [54].

Our first tests showed that SCREES (presence/absence of calcareous screes) was the most important variable, which explained above all the distribution of $P$. occidentale and largely hid other variable effects. As P. occidentale occurs only in calcareous screes, we, therefore, considered only the area with the presence of calcareous screes for the SDM (and SCREES was thus removed from variables in the models). Pseudo-absences (or background data) were generated inside this area. The number of pseudo-absences was selected to equal the number of presences. Pseudo-absences were randomly generated, which is the strategy with the least assumptions that should be used by default if there are no strong arguments in favour of a different approach $[47,55,56]$.

For future predictions under different climate change scenarios, we gathered raster data from Meteoswiss ([57], Table S3, Supplementary Materials). We used the data that includes the evolution of temperature and precipitation (annual, summer, winter) for the end of the century (sometime between the year 2070 and 2099, noted hereafter year 2085). Three different representative concentration pathway (RCP) scenarios were considered: RCP 2.6 (implies a strong reduction of greenhouse gas emissions early in the 21st century), RCP 4.5 (emissions decline after 2050, stabilization of radiative forcing), and RCP 8.5 (continuously increasing radiative forcing) [57,58].

On average, the annual mean temperature is expected to increase in Switzerland [57], from $+1.3^{\circ} \mathrm{C}$ (RCP 2.6) to $+4.4{ }^{\circ} \mathrm{C}$ (RCP 8.5). The actual mean precipitation in winter (PREC-Win data) was also replaced by the raster projections for 2085. On average, the mean winter precipitations are expected to increase in Switzerland from $+6 \%$ (RCP 2.6) to $+13 \%$ (RCP 8.5). On the contrary, summer precipitations are expected to decrease (but this variable was not retained in the final validated model). 
Table 1. Environmental variables selected for the Species Distribution Model (SDM) of Papaver occidentale.

\begin{tabular}{|c|c|c|c|c|c|}
\hline Abbreviation & Variable Type & Unit & Source & Native Resolution & Resolution Used in SDM \\
\hline ELEVATION & $\begin{array}{l}\text { Digital elevation model } \\
\text { (DEM) }\end{array}$ & Meters (m) & $\begin{array}{l}\text { swissALTI3D, The high } \\
\text { precision digital elevation } \\
\text { model of Switzerland [59] }\end{array}$ & $\begin{array}{c}2 \mathrm{~m} \text {, vertical uncertainty } \\
\pm 0.5 \mathrm{~m}<2000 \mathrm{~m} \\
1-3 \mathrm{~m}>2000 \mathrm{~m}\end{array}$ & $\begin{array}{l}\text { Upscaled to } 10 \mathrm{~m}, \\
\text { median value }\end{array}$ \\
\hline SLOPE & terrain inclination & Degrees $\left({ }^{\circ}\right)$ & Calculated from DEM & $2 \mathrm{~m}$ & $\begin{array}{l}\text { Upscaled to } 10 \mathrm{~m}, \\
\text { median value }\end{array}$ \\
\hline NORTHNESS & $\begin{array}{l}\text { Slope aspect on the } \\
\text { south-north axis }\end{array}$ & $\begin{array}{c}\text { No unit, a real number } \\
\text { between }-1 \text { (south) and } 1 \\
\text { (north) }\end{array}$ & $\begin{array}{l}\text { Calculated from DEM, } \\
\text { cosinus of the slope aspect }\end{array}$ & $2 \mathrm{~m}$ & $\begin{array}{l}\text { Upscaled to } 10 \mathrm{~m}, \\
\text { median value }\end{array}$ \\
\hline EASTNESS & $\begin{array}{l}\text { Slope aspect on the } \\
\text { west-east axis }\end{array}$ & $\begin{array}{c}\text { No unit, a real number } \\
\text { between }-1 \text { (west) and } 1 \\
\text { (east) }\end{array}$ & $\begin{array}{l}\text { Calculated from DEM, } \\
\text { sinus of the slope aspect }\end{array}$ & $2 \mathrm{~m}$ & $\begin{array}{l}\text { Upscaled to } 10 \mathrm{~m}, \\
\text { median value }\end{array}$ \\
\hline TEMP & $\begin{array}{l}\text { Mean yearly mean } \\
\text { temperature (norm, } \\
\text { 1981-2010) }\end{array}$ & degrees ${ }^{\circ} \mathrm{C}$ & Tnorm Y8110 [59] & $1000 \mathrm{~m}$ & $\begin{array}{l}\text { Downscaled to } 10 \mathrm{~m} \text {, using DEM to } \\
\text { improve resolution (strong negative } \\
\text { linear relationship between } \\
\text { ELEVATION and TEMP, R-squared } \\
\text { value }=0.92, p \text {-value }<0.001 \text {. TEMP } \\
\text { was thus calculated as a function of } \\
\text { ELEVATION, see Table S2, Figure } \\
\text { S1, Supplementary Materials) }\end{array}$ \\
\hline TEMP_Sum & $\begin{array}{c}\text { Mean summer mean } \\
\text { temperature (norm, } \\
\text { 1981-2010) }\end{array}$ & degrees ${ }^{\circ} \mathrm{C}$ & $\begin{array}{l}\text { TnormM8110 mean for } \\
\text { June, July and August [59] }\end{array}$ & $1000 \mathrm{~m}$ & $\begin{array}{l}\text { Downscaled to } 10 \mathrm{~m} \text {, same } \\
\text { procedure as TEMP }\end{array}$ \\
\hline TEMP_Win & $\begin{array}{l}\text { Mean winter mean } \\
\text { temperature (norm, } \\
\text { 1981-2010) }\end{array}$ & degrees ${ }^{\circ} \mathrm{C}$ & $\begin{array}{c}\text { TnormM8110, mean for } \\
\text { December, January and } \\
\text { February [59] }\end{array}$ & $1000 \mathrm{~m}$ & $\begin{array}{l}\text { Downscaled to } 10 \mathrm{~m} \text {, same } \\
\text { procedure as TEMP }\end{array}$ \\
\hline PREC & $\begin{array}{l}\text { Mean yearly precipitation } \\
\text { (norm, 1981-2010) }\end{array}$ & Millimeters (mm) & RnormY8110 [59] & $1000 \mathrm{~m}$ & $\begin{array}{c}\text { Downscaled to } 10 \mathrm{~m} \text {, using bicubic } \\
\text { spline interpolation to get a smooth } \\
\text { result (avoid artificial steps) }\end{array}$ \\
\hline PREC_Sum & $\begin{array}{l}\text { Mean summer } \\
\text { precipitation (norm, } \\
\text { 1981-2010) }\end{array}$ & Millimeters (mm) & $\begin{array}{l}\text { RnormM8110, mean for } \\
\text { June, July and August [59] }\end{array}$ & $1000 \mathrm{~m}$ & $\begin{array}{l}\text { Downscaled to } 10 \mathrm{~m} \text {, using bicubic } \\
\text { spline interpolation to get a smooth } \\
\text { result (avoid artificial steps) }\end{array}$ \\
\hline
\end{tabular}


Table 1. Cont

\begin{tabular}{|c|c|c|c|c|c|}
\hline Abbreviation & Variable Type & Unit & Source & Native Resolution & Resolution Used in SDM \\
\hline PREC_Win & $\begin{array}{l}\text { Mean winter precipitation } \\
\quad(\text { norm, 1981-2010) }\end{array}$ & Millimeters (mm) & $\begin{array}{c}\text { RnormM8110, mean for } \\
\text { December, January and } \\
\text { February [59] }\end{array}$ & $1000 \mathrm{~m}$ & $\begin{array}{l}\text { Downscaled to } 10 \mathrm{~m} \text {, using bicubic } \\
\text { spline interpolation to get a smooth } \\
\text { result (avoid artificial steps) }\end{array}$ \\
\hline SUNSHINE & $\begin{array}{c}\text { Mean yearly relative } \\
\text { sunshine duration (norm, } \\
\text { 1981-2010) }\end{array}$ & Percent (\%) & SnormY8110 [59] & $1000 \mathrm{~m}$ & $\begin{array}{l}\text { Downscaled to } 10 \mathrm{~m} \text {, using bicubic } \\
\text { spline interpolation to get a smooth } \\
\text { result (avoid artificial steps) }\end{array}$ \\
\hline IRRAD & $\begin{array}{l}\text { Total irradiance during } \\
\text { one day at the solstice } \\
\text { (21st June) }\end{array}$ & $\mathrm{Wh} / \mathrm{m}^{2} /$ day & $\begin{array}{l}\text { Calculate from DEM with } \\
\text { r.sun (Solar irradiance and } \\
\text { irradiation model) in } \\
\text { GRASS GIS [60] }\end{array}$ & $10 \mathrm{~m}$ & $10 \mathrm{~m}$ \\
\hline HOURS_SUN & $\begin{array}{c}\text { Hours of sun during one } \\
\text { day at the solstice (21st } \\
\text { June) }\end{array}$ & Hours (h) & $\begin{array}{l}\text { Calculate from DEM with } \\
\text { r.sun (Solar irradiance and } \\
\text { irradiation model) in } \\
\text { GRASS GIS [60] }\end{array}$ & $10 \mathrm{~m}$ & $10 \mathrm{~m}$ \\
\hline SCREES & $\begin{array}{l}\text { Landcover: area with } \\
\text { presence of calcareous } \\
\text { screes }\end{array}$ & Presence-absence (1-0) & $\begin{array}{l}\text { Area delimited using } \\
\text { GEOCOVER (Geological } \\
\text { vector datasets for better } \\
\text { subsurface management, } \\
\text { [61]) and interpretation of } \\
\text { orthophotos } \\
\text { (www.swisstopo.ch, } \\
\text { Google maps). A } 100 \mathrm{~m} \\
\text { buffer was added to the } \\
\text { delimited areas, as the } \\
\text { precise limit of the scree is } \\
\text { difficult to get. }\end{array}$ & NA, vector data. & Rasterized to $10 \mathrm{~m}$ \\
\hline
\end{tabular}




\subsection{Model Selection and Calibration}

Two logistic regression techniques were used for SDM: the general linear models (GLMs) and the general additive models (GAMs). GLMs are a generalization of ordinary linear regression. They allow the linear model to be related to the response variable via a link function [62]. For our purpose, the link function was the logistic function (logit) and we used quadratic functions of all environmental variables to allow for nonlinear relationships between the covariates and response variable. GAMs are GLMs in which the usual linear relationship between the response and covariates are replaced by several nonlinear smooth functions to model and capture the nonlinearities in the data [63-65].

All preselected environmental variables were first included in the models. Then, the significance of the variables in the model, the explained deviance, the AIC, Akaike information criterion, and BIC, Bayesian information criterion $[66,67]$ were checked to remove superfluous variables and build the most parsimonious model.

\subsection{Model Validation}

Different cross-validation techniques have been used to validate the model and prevent overfitting, like 10-fold cross-validation [47,68,69] and Monte-Carlo cross-validation [70,71]. However, our data were strongly spatially autocorrelated. Consequently, the 10-fold and the Monte-Carlo cross-validations were not suitable to validate our models (for example, the receiver operating characteristic (ROC) curves of validation datasets were always quasi identical to the ROC curve of the full model, see Figure S4, Supplementary Materials). We, therefore, designed a spatial cross-validation [72,73]. The studied area was split into two blocks on the W-E axis. The data within one block serves to train the model while the data in the second block serves to validate the model and vice versa. Then the same exercise was done with two blocks on the N-S axis. Presences and pseudo-absences were each time equilibrated. This validation procedure serves us mainly to delete environmental variables from the model that conduct to overfitting.

The results of cross-validation were analysed with a ROC curve [74]. The true positive rate was plotted against the false positive rate for each validation dataset, next to the full model ROC curve, which permits to investigate for overfitting problems. With validation datasets, the area under the curve (AUC) and mean squared residuals (MSR) served to evaluate the model performance.

The spatial cross-validation revealed strong overfitting of the models (both GLM and GAM). The models were thus simplified step-by-step (suppression of some environmental variables, decreasing the degree of smoothing in GAM or suppression of some quadratic terms in GLM), to optimize the dataset during the spatial cross-validation. We lastly also tried to add interaction terms, but they never improved the model and were thus not included. All calculations and graphs were done in R ([75], Table S4, Supplementary Materials). Maps and spatial analyses were created with QGIS [76].

\section{Results}

\subsection{Distribution and Population Size of Papaver occidentale}

The species could be confirmed in all sites indicated in the available sources (e.g., old and recent literature, reports, personal communication of local experts), and no new populations were discovered. Papaver occidentale possesses globally 21 populations (Figures 1 and 2, Table S1, Supplementary Materials) growing in six administrative units: 6 populations in the canton of Fribourg, 5 in Bern, 4 in Vaud, and 1 in Valais, as well as 5 populations in Haute-Savoie (France). Two populations of the canton of Vaud from the Jura Mountains are introduced (TEN and CUN, ancient introductions, [38]). Thus, the majority of 19 natural populations (74\%) are growing in Switzerland.

The total population size of natural occurrences of P. occidentale was estimated at 30,756 individuals (estimation from 153 GPS locations). The two introduced sites in the Jura Mountains are very poor in individuals (TEN: 6, CUN: 1). The largest population grows in the canton of Bern (Hinderi Fromatt), with 9851 individuals. Generally, the canton of Bern with 22,117 (72\%) of all individuals taken together, 
is the main distribution center of the taxon. Canton of Fribourg has 5167 (17\%), Vaud $748(2.5 \%)$ and Valais $141(0.5 \%)$ individuals. Haute-Savoie, and thus France, counts 2547 individuals, and thus merely $8 \%$ of all individuals of the species (Figures 1 and 2).

The species grows in the majority of natural sites between 1900 and $2100 \mathrm{~m}$ a.s.l. and on the northern slopes (Figure 3, Table S1, Supplementary Materials), usually between 100 and $300 \mathrm{~m}$ from the highest summit. The highest mean elevation of P. occidentale occurrence (2400 $\mathrm{m}$ a.s.l.) was measured in the population on Pointe Blanche (PTB) in Haute-Savoie as well as in the canton of Fribourg, with 2300 $\mathrm{m}$ a.s.l. on Pointe de Paray (PAR) and with $2235 \mathrm{~m}$ a.s.l. at Combe Vanil de l'Ecri (COM). The natural populations with the lowest mean altitude occur in the canton of Vaud, with $1760 \mathrm{~m}$ a.s.l. in Les Salaires (SAL) and with $1653 \mathrm{~m}$ a.s.l. in La Pierreuse (PIE). The two very small and introduced populations of Jura are growing also at very low altitudes (TEN: $1658 \mathrm{~m}$ a.s.l and CUN: $1571 \mathrm{~m}$ a.s.l.) (Table S1, Supplementary Materials).
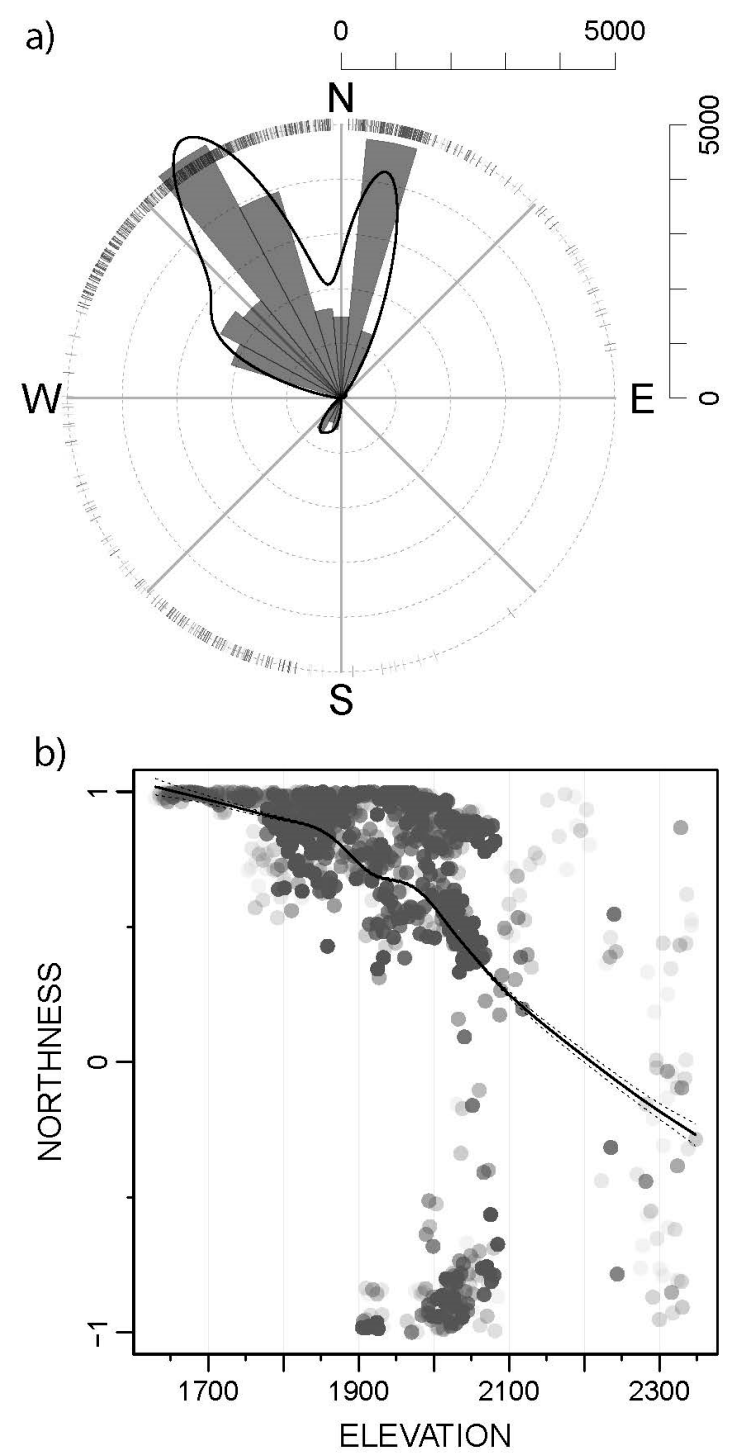

Figure 3. (a) Radial histogram indicating the number of Papaver occidentale individuals according to the slope aspect. The small surrounding ticks indicate single individuals and the black solid line gives a smooth approximation, calculated with a GAM. (b) Northness (N-S slope aspect, values from -1 : south to 1: north) as a function of elevation (meters), for all P. occidentale individuals in the studied area (grey dots). The black line shows a smooth approximation of the mean (GAM fit, with a $95 \%$ confidence interval). 


\subsection{Species Distribution Modelling}

A total of 28,209 individuals (presences) were comprised in the area considered for the SDM (representing $92 \%$ of all individuals and $74 \%$ of all natural populations). Thus, the number of pseudo-absences randomly generated (in the area with calcareous screes, see methods), was 28,209 as well.

The different steps of model calibration and validation are described in Table S2 (Supplementary Materials). The final validated model chosen to predict $P$. occidentale habitat suitability was a GAM (which performed slightly better than the GLM during the validation procedure) including the following four environmental variables: SLOPE, TEMP (mean annual temperature), NORTHING (north-south aspect of the slope), PREC_Win (mean winter precipitation). It explained $58.64 \%$ of the total variance. The mean AUC of the validation datasets during the spatial cross-validation was 0.9. The four included variables were significant ( $p$-value $<0.001$ ). The best threshold calculated from the ROC curve was 0.55 (Figure S1, Table S5, Supplementary Materials).

\subsection{Predicted Habitat Suitability and Ecological Preferences}

According to our model, in the studied area $\left(2335 \mathrm{~km}^{2}\right)$, the habitat can be considered as suitable (predicted value $>0.55)$ for $P$. occidentale on $33 \mathrm{~km}^{2}(1.4 \%)$. The species effectively occurs in an area of about $1 \mathrm{~km}^{2}$ (Figure 4).

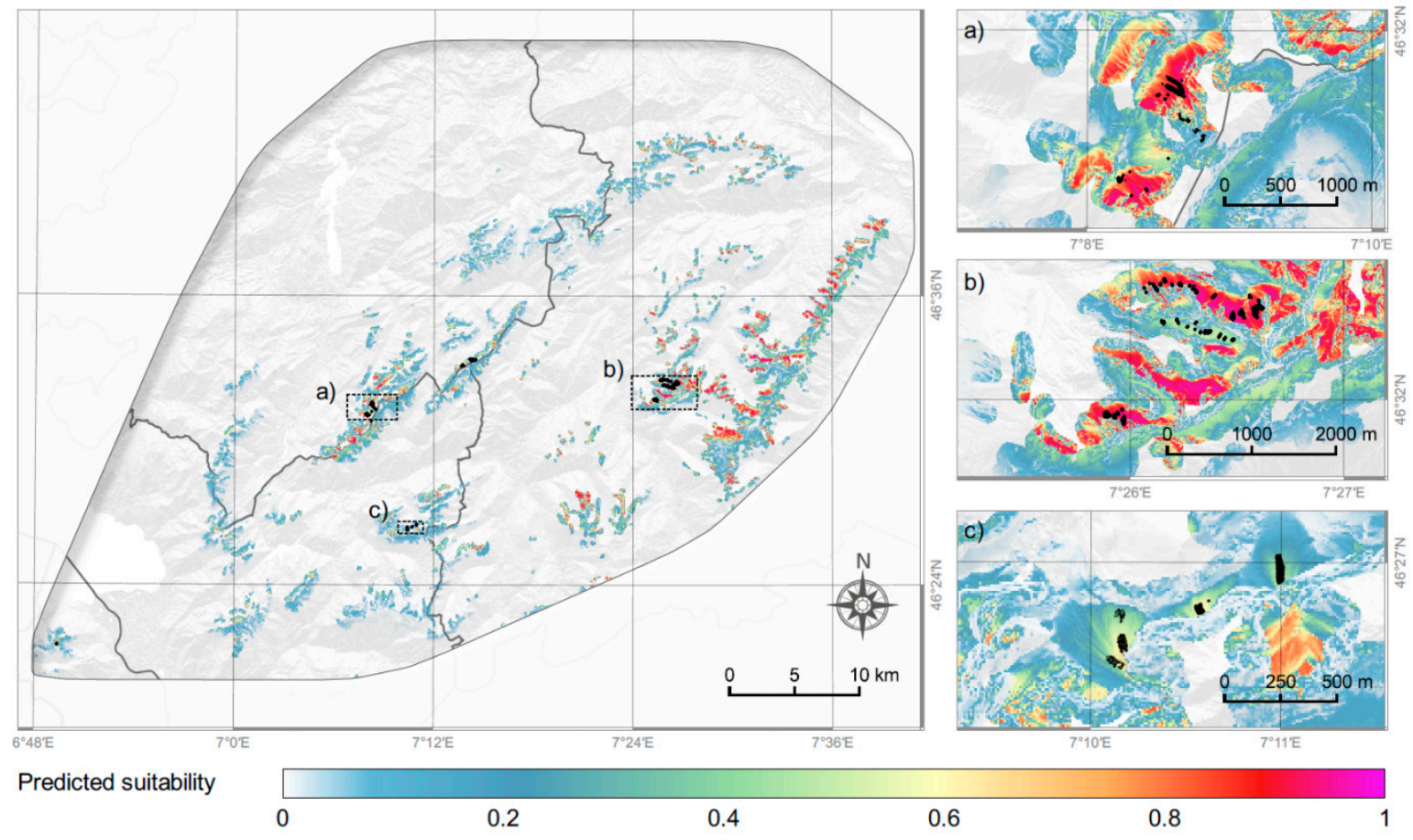

Figure 4. Modelled current habitat suitability of Papaver occidentale in the Western Swiss Prealps. White areas are less suitable, red and purple are the most suitable. Three areas are zoomed on the right panel (a, Vanil Noir region; b, Spillgerte region; c, Gummfluh region). The black dots indicate the locations of $P$. occidentale (presences).

The most important environmental variables that influence the distribution of $P$. occidentale are those included in the final model, namely the slope (SLOPE), the mean annual temperature (TEMP) and the slope orientation (NORTHNESS). More surprisingly, the mean precipitation during the winter (PREC_Win) also contributes to explaining the species distribution. The response curve of these four variables can be found in Figure S5 (Supplementary Materials). The ecological preferences of P. occidentale concerning some selected environmental variables are shown in Figure 5. 
A small percentage of $P$. occidentale individuals were growing on south-facing slopes, however only above $1900 \mathrm{~m}$ a.s.l. Below $1900 \mathrm{~m}$ a.s.l. all individuals were only growing on north facing slopes. Above this elevation, the slope aspect becomes less important (Figure 3).

The model was used to predict habitat suitability of $P$. occidentale under different climate change scenarios (RCP 2.6, RCP 4.5 and RCP 8.5, see Methods), for the end of the century (year 2085, Table 2, Figure 6). The suitable area will be drastically reduced, both for all populations of $P$. occidentale in the study area and for all climatic scenarios. For the entire studied area reduction to $0-30 \%$ is predicted, of the current P. occidentale populations. Under the most severe scenario (RCP 8.5), the species risks complete extinction, and this is not only for small isolated populations but also for all five individual-rich and large-surface populations of Spillgerte in the canton of Bern (Table 2, Figure 6).

Table 2. Remaining suitable area (predicted value $>0.55$ ) under different climate change scenarios (RCP 2.6, RCP 4.5 and RCP 8.5), at the end of the century for Papaver occidentale. The remaining future suitable areas are given as a percentage of the actual suitable predicted area.

\begin{tabular}{cc}
\hline Climatic Change Scenario & Remaining Suitable Area (Entire Studied Area) \\
\hline Actual & $100 \%$ \\
RCP 2.6, year 2085 & $30 \%$ \\
RCP 4.5, year 2085 & $4 \%$ \\
RCP 8.5, year 2085 & $0 \%$ \\
\hline
\end{tabular}
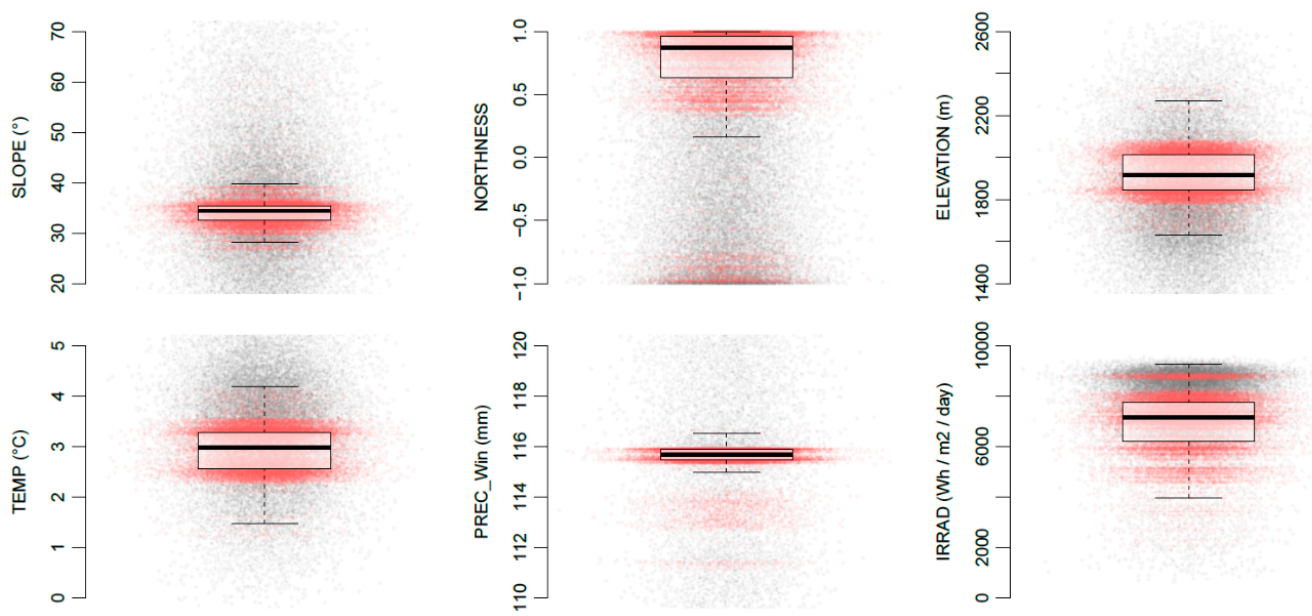

Figure 5. Ecological preferences of Papaver occidentale concerning some selected environmental variables. P. occidentale individuals are represented by red dots and background (pseudo-absences) are represented by grey dots. The box plots summarize the preference of $P$. occidentale concerning each variable. ELEVATION and IRRAD (total irradiance, see Table 1) are shown but were not included in the final model. 

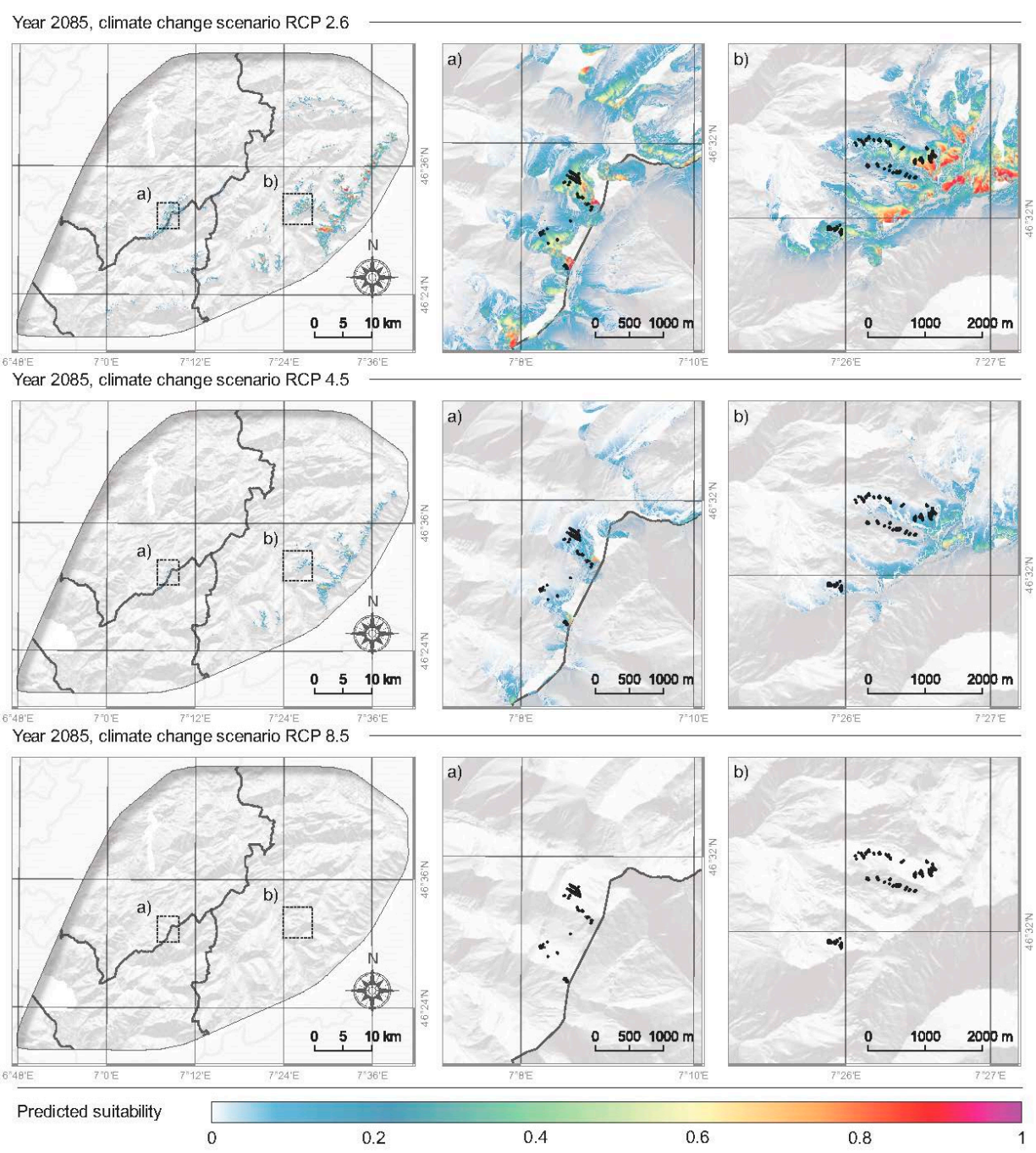

Figure 6. Modelled future habitat suitability of Papaver occidentale in the Western Swiss Prealps, under different climate change scenarios (RCP 2.6, RCP 4.5 and RCP 8.5), at the end of the century (year 2085). White areas are less suitable, red and purple are the most suitable. Two areas are zoomed on the right panel (a, Vanil Noir region; b, Spillgerte region). Black dots indicate the location of present P. occidentale populations.

\section{Discussion}

Our study demonstrates that $P$. occidentale is a highly specialized, cold-adapted alpine plant. It grows in natural sites mainly between 1900 and $2100 \mathrm{~m}$ of altitude, and all populations and individuals that grow under $1900 \mathrm{~m}$ a.s.l. are strictly confined to north-facing screes. Although some populations (e.g., in the canton of Bern) show locally relatively high number of individuals, the present distribution pattern and the extremely small effectively occupied area, left no doubt: $P$. occidentale likely reaches today the strongest reduction of its distribution range in the evolutionary history of this taxon.

Papaver occidentale, along with all members of the P. alpinum complex, belongs to the section Meconella, and shows a large number of morphological and ecological similarities with other members of this taxonomic group [30]. The Meconella poppies (ca. 50 species) are an evolutionarily young and taxonomically poorly understood branch, mainly due to a Pleistocene or perhaps even later speciation of the majority of its members [77,78]. All species of this section are specialized arctic-alpine poppies, adapted to survive in the harshest (edaphically and climatically) ecosystems inhabited by vascular plants [79]. However, the P. alpinum group is the most basal in the sect. Meconella [26,27] and some authors proposed that it colonized the Alps rather from the east than from the north [31]. 
Nevertheless, Meconella poppies were among the very first immigrants after the Last Glacial Maximum in the high Arctic [80]. Notably, P. radicatum was probably among the earliest colonizers of deglaciated parts of northern Norway between the 13,000 and 14,000 years BP [28]. Papaver radicatum is also today nearly the only vascular plant (along with Saxifraga oppositifolia) inhabiting the northernmost piece of land in the Northern Hemisphere (islet of Kaffeklubben, northern Greenland) [79]. Another species of the Meconella section, P. dahlianum, forms floristically poor communities on Svalbard and occupies similar habitats to $P$. occidentale (scree-covered mountain slopes), but also gravel beds and moraines. The species is also among the very first immigrants growing on moraines left behind the retracting glaciers on Svalbard [81]. Furthermore, P. dahlianum makes part of a restricted number of vascular plants capable of growing, flowering and yielding seeds at the average daily temperature slightly over $0{ }^{\circ} \mathrm{C}$ [82], and reaching on Svalbard altitude of $940 \mathrm{~m}$ a.s.l. [83].

In the northeastern and southeastern Alps, individual plants and even large populations of P. alpinum s.l. were observed in gravel river beds and roadsides at low altitudes [31]. Therefore, it is highly probable, that during the last glacial period, ancestors and/or relatives of $P$. occidentale were frequent in the vast alluvial terraces surrounding the central glaciated part of the Alps. They then followed the retracting glaciers and survived only in very few isolated and extremely small areas [30]. However, recent molecular data indicate that both local survival and immigration from edge alpine refugia played an important role during the recolonization of the Western Prealps by P. occidentale, leading to a complex genetic pattern [34]. Papaver occidentale is clearly in a refugial situation today.

\subsection{Current Geographic Range}

According to SDM, the habitats that can be considered as suitable for P. occidentale in the studied area reach about $33 \mathrm{~km}^{2}$. However, the effective area where the species occurs does not exceed $1 \mathrm{~km}^{2}$. There are likely two main reasons why the realized niche is much more restricted than the fundamental niche. Firstly, the history of the recolonization of the Alps by P. occidentale after the last glacial maximum is complex. It probably followed the retracting glaciers in some valleys on the moraines, but not in all of them. With the Holocene climate warming, the species was blocked in these valleys and was unable to reach other parallel valleys because of its limited dispersion potential. It moreover probably became extinct in some areas. The high genetic isolation of some geographically close populations, could support such a scenario or a possible local in situ survival without postglacial expansion [1].

The second reason is the method of the delimitation of calcareous screes, which could lead to a certain bias. Some delimited screes on orthophotos were included in the studied area, but might not be suitable for the species (scree already too stabilized, presence of competitive vegetation, etc.). This led to an over-optimistic suitable area, but the percentage of reduction of those suitable areas under future climate change scenarios is proportional, and thus reliable.

\subsection{No Future for P. occidentale?}

Thuiller et al. [84] estimated that up to $48.5 \%$ of mountain plant species in the European Alps are at risk of extinction due to the accelerated climate change. Papaver occidentale belongs without doubts to the group of alpine plants, which are the most exposed to the ongoing global warming. According to our results, the remaining suitable area will be drastically reduced, even by the weakest global warming scenario. By the RCP 8.5 climate change scenario, P. occidentale will face a complete extinction by 2085 across its whole distribution area. The severe future range contraction predicted for P. occidentale reflects similar results for other alpine endemic species, e.g., Berardia subacaulis [85] or Lilium pomponium [86]. It was often concluded, that global warming may result in a significant upward shift in species optimum elevation [87], giving the threatened species an additional survival option. However, marginal Western Prealps have relatively low summit heights, making their alpine plant populations particularly vulnerable to extinction [25,88]. Additionally, P. occidentale is confined to calcareous scree habitats, which will not enlarge their surface until the end of the 21st century. Although exceptionally at highest elevations, isolated individual plants can be found growing in 
weathered crevices of calcareous rocks, an altitudinal shift does not appear to be a viable option for this taxon.

Several studies demonstrated that alpine plants' response to climate warming might be much slower than predicted using standard species distribution models [89,90]. Additionally, even highly specialized and/or endemic plants can defy unfavorable climatic conditions and persist for millennia in so-called topo-climatic microrefugia, as was demonstrated for Saxifraga florulenta in the Alps [91] or a relict lineage of Ranunculus glacialis in the Carpathians [16]. In extreme cases, exiguous spots can ensure long-term survival of isolated relict populations [92]. Our study, however, is a rare example of SDM specifically developed for plants inhabiting calcareous screes, enhancing thus its precision and reliability. Plants inhabiting calcareous screes will probably react faster than other plant communities (e.g., subalpine grasslands, [93]).

\subsection{Conservation Implications}

The entire native distribution area of $P$. occidentale consists of only 19 populations grouped in six isolated regions, with the total number of individuals estimated at slightly more than 30,000. Surprisingly, the region of Spillgerte (comprising all 5 populations of the canton of Bern), harbors more than $72 \%$, and thus a huge portion of the total number of individuals. Such domination in this region is an important discovery of the present study, since the only reports on P. occidentale available to date, attributed regions of Fribourg and Vaud as the main distribution centers of this taxon [38]. Furthermore, the five populations of the canton of Bern represent a unique genetic composition, being highly differentiated in comparison with all the other populations [34]. These results should be therefore taken into consideration for prioritizing future conservation efforts. The introduced plants in the Jura Mountains grow in a habitat that is very different from the natural ones [38,94,95]. The very low number of individuals in the introduced region, detected in our survey, confirms that P. occidentale has very specific habitat requirements and cannot prosper in any other habitat. Thus, no conservation efforts should be undertaken for these non-natural populations.

Despite its quite narrow distribution and its very specialized environmental requirements, the P. occidentale populations are not threatened by any direct human activity in the short term. The steep and mobile calcareous screes are habitats that are not appropriate for any human activity. Merely a few hiking trails get close to populations [38]. Wild animals do not put the species under extinction risk either. Ibexes and chamois have been observed in the vicinity but only a few individuals have been reported as grazed [39]. Thus, according to our study, global warming will be the main (if not the only) factor threatening the last remaining populations of $P$. occidentale in the near future.

Our results confront local nature conservation authorities with major challenges. The long-term in situ conservation of P. occidentale, and probably all other taxa of the P. alpinum complex, as well as other glacial relicts in the Alps, is unlikely to be achieved without slowing global climate change.

Supplementary Materials: The following are available online at http://www.mdpi.com/1424-2818/12/9/346/s1, Table S1. Populations of P. occidentale and estimated population sizes (number of individuals). Table S2. Additional information related to SDM. Table S3. Information on climate change scenarios data. Table S4. R script. Table S5. Cross-validation of the final validated GAM: AUC and MSR of the validated model, with different cross-validation techniques. Table S6. Full-field counting data. Figure S1. Series of maps representing environmental variables on the studied area. The right panels show 3 zoomed areas where P. occidentale occurs (see Figure 4 in the main manuscript). Figure S2. Paired correlation plot with all environmental variables. For the meaning of abbreviations, see Table 1 in the main manuscript. Figure S3. Paired correlation plot with the 8 selected (uncorrelated) environmental variables. For the meaning of abbreviations, see Table 1 in the main manuscript. Figure S4. Receiver operating characteristic (ROC) curves for different cross-validation techniques (red line, full model ROC curve with all the data, grey lines, ROC curves of validation datasets). Figure S5. Response curves for the final validated General Additive Model (GAM).

Author Contributions: G.K. and Y.F. conceived the idea. L.P., S.B., B.C. and E.G. conducted the fieldwork. Y.F. conducted statistical and modelling analyses. G.K., M.R. and C.P. edited the manuscript. All authors have read and agreed to the published version of the manuscript.

Funding: M.R. is financially supported by the statutory funds of the W. Szafer Institute of Botany, Polish Academy of Sciences. 
Acknowledgments: We would like to thank Peter Wandeler from the Natural History Museum in Fribourg (Switzerland) for his advice and the financial support, Denis Jordan (France), Sarah Kasraian, David Giovannini and Beat Wolf. Finally, we thank Francesca Cheda from the Nature Protection Office of the Canton Fribourg (Switzerland), Brigitte Holzer from the Nature Protection Office of the Canton Bern (Switzerland), Olivier Guex from the Service des forrets, des cours d'eau et du paysage of the Canton Valais (Switzerland) and Franco Ciardo from the Direction générale de l'environnement of the Canton Vaud for the permissions.

Conflicts of Interest: The authors declare no conflict of interest.

\section{References}

1. Jiménez-Alfaro, B.; García-Calvo, L.; García, P.; Luis Acebes, J. Anticipating extinctions of glacial relict populations in mountain refugia. Biol. Conserv. 2016, 201, 243-251. [CrossRef]

2. Arrigo, N.; Bétrisey, S.; Graf, L.; Bilat, J.; Gerber, E.; Kozlowski, G. Hybridization as a threat in climate relict Nuphar pumila (Nymphaeaceae). Biodiv. Conserv. 2016, 25, 1863-1877. [CrossRef]

3. Zecca, G.; Casazza, G.; Piscopo, S.; Minuto, L.; Grassi, F. Are the responses of plant species to Quaternary climatic changes idiosyncratic? A demographic perspective from Western Alps. Plant Ecol. Divers. 2017, 10, 273-281. [CrossRef]

4. Schönswetter, P.; Schneeweiss, G.M. Is the incidence of survival in interior Pleistocene refugia (nunataks) underestimated? Phylogeography of the high mountain plant Androsace alpina (Primulaceae) in the European Alps revisited. Ecol. Evol. 2019, 9, 4078-4086. [CrossRef]

5. Hampe, A.; Jump, A.S. Climate relicts: Past, present, future. Annu. Rev. Ecol. Evol. 2011, 42, $313-333$. [CrossRef]

6. Woolbright, S.A.; Whitham, T.G.; Gering, C.A.; Allan, G.J.; Bailey, J.K. Climate relicts and their associated communities as natural ecology and evolution laboratories. Trends Ecol. Evol. 2014, 29, 406-416. [CrossRef]

7. Taberlet, P.; Fumagalli, L.; Wust-Saucy, A.-G.; Cosson, J.-F. Comparative phylogeography and postglacial colonization routes in Europe. Mol. Ecol. 1998, 7, 453-464. [CrossRef] [PubMed]

8. Brochmann, C.; Gabrielsen, T.M.; Nordal, I.; Landvik, J.Y.; Elven, R. Glacial survival or tabula rasa? The history of North Atlantic biota revisited. Taxon 2003, 52, 417-450.

9. Tribsch, A.; Schönswetter, P. Patterns of endemism and comparative phylogeography confirm palaeoenvironmental evidence for Pleistocene refugia in the eastern Alps. Taxon 2003, 52, 477-497. [CrossRef]

10. Holderegger, R.; Thiel-Egenter, C. A discussion of different types of glacial refugia used in mountain biogeography and phylogeography. J. Biogeogr. 2009, 36, 476-480. [CrossRef]

11. Berthouzoz, M.; Maendly, S.; Bétrisey, S.; Mangili, S.; Prunier, P.; Lexer, C.; Kozlowski, G. Some like it cold: Distribution, ecology and phylogeny of Arenaria bernensis Favarger (Caryophyllaceae) from the Western Prealps in Switzerland. Alp. Bot. 2013, 123, 65-75. [CrossRef]

12. Windmaisser, T.; Kattari, S.; Heubl, G.; Reisch, C. Glacial refugia and postglacial expansion of the alpine-prealpine plant species Polygala chamaebuxus. Ecol. Evol. 2016, 6, 7809-7819. [CrossRef] [PubMed]

13. Stehlik, I.; Blattner, F.; Holderegger, R.; Bachmann, K. Nunatak survival of the high alpine plant Eritrichium nanum (L.) Gaudin in the Central Alps during the ice ages. Mol. Ecol. 2002, 11, 2027-2036. [CrossRef] [PubMed]

14. Stehlik, I. Resistance or emigration? Response of alpine plants to the ice ages. Taxon 2003, 52, 499-510. [CrossRef]

15. Paun, O.; Schönswetter, P.; Winkler, M.; Consortium, I.; Tribsch, A. Historical divergence vs. contemporary gene flow: Evolutionary history of the calcicole Ranunculus alpestris group (Ranunculaceae) in the European Alps and the Carpathians. Mol. Ecol. 2008, 17, 4263-4275. [CrossRef]

16. Ronikier, M.; Schneeweis, G.M.; Schönswetter, P. The extreme disjunction between Beringia and Europe in Ranunculus glacialis sl. (Ranunculaceae) does not coincide with the deepest genetic split-A story of the importance of temperate mountain ranges in arctic-alpine phylogeography. Mol. Ecol. 2012, 21, 5561-5578. [CrossRef]

17. Winkler, M.; Tribsch, A.; Schneeweis, G.M.; Brodbeck, S.; Gugerli, F.; Holderegger, R.; Abbott, R.J.; Schönswetter, P. Tales of the unexpected: Phylogeography of the arctic-alpine model plant Saxifraga oppositifolia (Saxifragaceae) revisited. Mol. Ecol. 2012, 21, 4618-4630. [CrossRef] 
18. Eidesen, P.B.; Ehrich, D.; Bakkestuen, V.; Alsos, I.G.; Gilg, O.; Taberlet, P.; Brochmann, C. Genetic roadmap of the Arctic: Plant dispersal highways, traffic barriers and capitals of diversity. New Phytol. 2013, 200, 898-910. [CrossRef]

19. Schmitt, T.; Muster, C.; Schönswetter, P. Are Disjunct Alpine and Arctic-Alpine Animal and Plant Species in the Western Palearctic Really "Relics of the Cold Past"; Habel, J.C., Assman, T., Eds.; Relict Species: Phylogeny and Conservation Biology; Springer: Berlin/Heidelberg, Germany, 2010; pp. 239-252.

20. Zimmermann, M.; Vischer-Leopold, M.; Ellwanger, G.; Ssymak, A.; Schröder, E. The EU Habitat Directive and the German Natura 2000 Network of Protected Areas as Tool for Implementing the Conservation of Relict Species; Habel, J.C., Assman, T., Eds.; Relict Species: Phylogeny and Conservation Biology; Springer: Berlin/Heidelberg, Germany, 2010; pp. 323-340.

21. Parisod, C.; Besnard, G. Glacial in situ survival in the Western Alps and polytopic autopolyploidy in Biscutella laevigata L. (Brassicaceae). Mol. Ecol. 2007, 16, 2755-2767. [CrossRef]

22. Hess, H.E.; Landolt, E.; Hirzel, R. Flora der Schweiz und Angrenzender Gebiete; Birkhäuser Verlag: Basel, Switzerland, 1977; Volume 2, p. 955.

23. Richard, J.-L. La végétation du Vanil Noir et du Vallon des Morteys. Bul. Soc. Frib. Sc. Nat. 1977, 66, 1-52.

24. Aeschimann, D.; Lauber, K.; Moser, D.M.; Theurillat, J.-P. Flora Alpina. Band 1-3; Haupt: Bern, Switzerland, 2004.

25. Gerber, E.; Kozlowski, G.; Mariéthoz, A. La flore des Préalpes du lac de Thun au Léman; Rossolis: Bussigny, Switzerland, 2010.

26. Kadereit, J.W.; Schwarzbach, A.E.; Jork, K.B. The phylogeny of Papaver s.l. (Papaveraceae): Polyphyly or monophyly? Plant Syst. Evol. 1997, 204, 75-98. [CrossRef]

27. Carolan, J.C.; Hook, I.L.I.; Chase, M.W.; Kadereit, J.W.; Hodkinson, T.R. Phylogenetics of Papaver and related genera based on DNA sequences from ITS nuclear ribosomal DNA and plastid trnL intron and trnL-F intergenic spacers. Ann. Bot. 2006, 98, 141-155. [CrossRef] [PubMed]

28. Nordal, I.; Hestmark, G.; Solstad, H. Reproductive biology and demography of Papaver radicatum-A key species in Nordic plant geography. Opera Bot. 1997, 132, 77-87.

29. Solstad, H.; Elven, R.; Nordal, I. Isozyme variation among and within North Atlantic species of Papaver sect. Meconella (Papaveraceae) and taxonomic implications. Biol. J. Linn. Soc. 2003, 143, 255-269. [CrossRef]

30. Kadereit, J.W. Notes on the taxonomy, distribution, phylogeny and ecology of Papaver alpinum L. (Papaveraceae). Bot. Jahrb. Syst. 1990, 112, 79-97.

31. Schönswetter, P.; Solstad, H.; Escobar, G.P. A combined molecular and morphological approach to the taxonomically intricate European mountain plant Papaver alpinum s.l. (Papaveraceae)—Taxa or informal phylogeographical groups? Taxon 2009, 58, 1326-1348. [CrossRef]

32. Markgraf, F. Papaveraceae. In Illustrierte Flora von Mitteleuropa, 2nd ed.; Hegi, G., Ed.; Hanser: München, Germany, 1958; Volume IV, pp. 15-49.

33. Markgraf, F. Eine neue Gliederung der Alpenmohne. Phyton 1958, 7, 302-314.

34. Pittet, L.; Fragnière, Y.; Grünig, S.; Bétrisey, S.; Clément, B.; Gerber, E.; Ronikier, R.; Kozlowski, G.; Parisod, C. Genetic structure of the narrow endemic Papaver occidentale indicates complex patterns of survival and immigration in the Western Prealps. Alp. Bot. 2020. [CrossRef]

35. Bornand, C.; Gygax, A.; Juillerat, P.; Jutzi, M.; Möhl, A.; Rometsch, S.; Sager, L.; Santiago, H.; Eggenberg, S. Rote Liste Gefässpflanzen. Gefährdete Arten der Schweiz. Umwelt-Vollzug Nr. 1621; Bundesamt für Umwelt: Bern, Switzerland, 2016.

36. Jordan, D. La Flore Rare ou Menacée de Haute-Savoie; Naturalia Publications: Turriers, France, 2015.

37. Bornand, C.; Hoffer-Massard, F. La Pierreuse ou le parfum du pavot, le 20 juillet 2002. Bull. Cercle Vaud. Bot. 2003, 32, 53-61.

38. Delarze, R. Plan d'action pour Papaver occidentale (Markgraf) H.E. Hess E Landolt (Pavot des Alpes occidentales); Coordination Régionale pour la Protection de la flore: Lausanne, Switzerland, 2012.

39. Bétrisey, S. Adaptation du Plan d'action Pour Papaver Occidentale; Jardin botanique de l'Université de Fribourg: Fribourg, Switzerland, 2014.

40. Guisan, A.; Thuiller, W. Predicting species distribution: Offering more than simple habitat models. Ecol. Lett. 2005, 8, 993-1009. [CrossRef]

41. Elith, J.; Leathwick, J.R.J.R. Species distribution models: Ecological explanation and prediction across space and time. Annu. Rev. Ecol. Evol. Syst. 2009, 40, 677-697. [CrossRef] 
42. Peterson, A.T.; Soberón, J.; Pearson, R.G.; Anderson, R.P.; Martínez-Meyer, E.; Nakamura, M.; Araújo, M.B. Ecological Niches and Geographic Distributions (MPB-49); Princeton University Press: Princeton, NJ, USA, 2011; Volume 56.

43. Peterson, A.T.; Soberón, J. Species distribution modeling and ecological niche modeling: Getting the concepts right. Nat. Conserv. 2012, 10, 102-107. [CrossRef]

44. Song, Y.-G.; Petipierre, B.; Deng, M.; Wu, J.-P.; Kozlowski, G. Predicting climate change impacts on the threatened Quercus arbutifolia in montane cloud forests in southern China and Vietnam: Conservation implications. For. Ecol. Manag. 2019, 444, 269-279. [CrossRef]

45. Buri, A.; Grand, S.; Yashiro, E.; Adatte, T.; Spangenberg, J.E.; Pinto-Figueroa, E.; Verrecchia, E.; Guisan, A. What are the most crucial soil variables for predicting the distribution of mountain plant species? A comprehensive study in the Swiss Alps. J. Biogeogr. 2020, 47, 1143-1153. [CrossRef]

46. Hageer, Y.; Esperón-Rodríguez, M.; Baumgartner, J.B.; Beaumont, L.J. Climate, soil or both? Which variables are better predictors of the distributions of Australian shrub species? PeerJ 2017, 5, e3446. [CrossRef]

47. Guisan, A.; Thuiller, W.; Zimmermann, N.E. Habitat Suitability and Distribution Models: With Applications in R; Cambridge University Press: Cambridge, UK, 2017.

48. Graham, M.H. Confronting multicollinearity in ecological multiple regression. Ecology 2003, 84, $2809-2815$. [CrossRef]

49. Braunisch, V.; Coppes, J.; Arlettaz, R.; Suchant, R.; Schmid, H.; Bollmann, K. Selecting from correlated climate variables: A major source of uncertainty for predicting species distributions under climate change. Ecography 2013, 36, 971-983. [CrossRef]

50. Júnior, P.D.M.; Nóbrega, C.C. Evaluating collinearity effects on species distribution models: An approach based on virtual species simulation. PLoS ONE 2018, 13, e0202403.

51. Craney, T.A.; Surles, J.G. Model-dependent variance inflation factor cutoff values. Qual. Eng. 2002, 14, 391-403. [CrossRef]

52. O'Brien, R.M. A caution regarding rules of thumb for variance inflation factors. Qual. Quant. 2007, 41, 673-690. [CrossRef]

53. Neteler, M.; Mitasova, H. Open Source GIS: A GRASS GIS Approach; Springer Science \& Business Media: Berlin, Germany, 2013; Volume 689.

54. Menard, S. Applied Logistic Regression Analysis; Sage: Los Angeles, CA, USA, 2002; Volume 106.

55. Wisz, M.S.; Guisan, A. Do pseudo-absence selection strategies influence species distribution models and their predictions? An information-theoretic approach based on simulated data. BMC Ecol. 2009, 9, 8. [CrossRef] [PubMed]

56. Barbet-Massin, M.; Jiguet, F.; Albert, C.H.; Thuiller, W. Selecting pseudo-absences for species distribution models: How, where and how many? Methods Ecol. Evol. 2012, 3, 327-338. [CrossRef]

57. CH2018 Climate Scenarios for Switzerland; Technical Report; National Centre for Climate Services: Zurich, Switzerland, 2018; pp. 1-271.

58. Van Vuuren, D.P.; Edmonds, J.; Kainuma, M.; Riahi, K.; Thomson, A.; Hibbard, K.; Hurtt, G.C.; Kram, T.; Krey, V.; Lamarque, J.-F.; et al. The representative concentration pathways: An overview. Clim. Chang. 2011, 109, 5. [CrossRef]

59. Swisstopo. Metadata of the GeoCover V2 Product. 2018. Available online: https://shop.swisstopo.admin.ch/ en/products/height_models/alti3D (accessed on 2 March 2020).

60. MeteoSwiss. Monthly and Annual Reports. Federal Office of Meteorology and Climatology. Available online: https://www.meteoswiss.admin.ch (accessed on 2 March 2020).

61. Swisstopo. Bundesamt für Landestopografie swisstopo-swissALTI3D-Das hoch aufgelöste Terrainmodell der Schweiz. Available online: https://shop.swisstopo.admin.ch/en/products/maps/geology/GC_VECTOR (accessed on 2 March 2020).

62. McCullagh, P. Generalized Linear Models; Routledge: London, UK, 2019.

63. Guisan, A.; Edwards, T.C., Jr.; Hastie, T. Generalized linear and generalized additive models in studies of species distributions: Setting the scene. Ecol. Model. 2002, 157, 89-100. [CrossRef]

64. Hastie, T.J. Generalized additive models. In Statistical Models in S; Routledge: London, UK, 2017; pp. $249-307$.

65. Wood, S.N. Generalized Additive Models: An Introduction with R; Chapman and Hall/CRC: London, UK, 2017.

66. Atkinson, A.C. A note on the generalized information criterion for choice of a model. Biometrika 1980, 67, 413-418. [CrossRef] 
67. Sakamoto, Y.; Ishiguro, M.; Kitagawa, G. Akaike Information Criterion Statistics; D. Reidel 81: Dordrecht, The Netherlands, 1986.

68. Rodriguez, J.D.; Perez, A.; Lozano, J.A. Sensitivity analysis of k-fold cross validation in prediction error estimation. IEEE Trans. Pattern Anal. Mach. Intell. 2009, 32, 569-575. [CrossRef] [PubMed]

69. Lever, J.; Krzywinski, M.; Altman, N. Points of significance: Model selection and overfitting. Nat. Methods 2016, 13, 703-704. [CrossRef]

70. Shao, J. Linear model selection by cross-validation. J. Am. Stat. Assoc. 1993, 88, 486-494. [CrossRef]

71. Xu, Q.S.; Liang, Y.Z. Monte Carlo cross validation. Chemomet. Intell. Lab. Syst. 2001, 56, 1-11. [CrossRef]

72. Pohjankukka, J.; Pahikkala, T.; Nevalainen, P.; Heikkonen, J. Estimating the prediction performance of spatial models via spatial k-fold cross validation. Int. J. Geogr. Inf. Sci. 2017, 31, 2001-2019. [CrossRef]

73. Roberts, D.R.; Bahn, V.; Ciuti, S.; Boyce, M.S.; Elith, J.; Guillera-Arroita, G.; Hauenstein, S.; Lahoz-Monfort, J.J.; Schröder, B.; Thuiller, W.; et al. Cross-validation strategies for data with temporal, spatial, hierarchical, or phylogenetic structure. Ecography 2017, 40, 913-929. [CrossRef]

74. Hanley, J.A.; McNeil, B.J. The meaning and use of the area under a receiver operating characteristic (ROC) curve. Radiology 1982, 143, 29-36. [CrossRef] [PubMed]

75. R Core Team. R: A Language and Environment for Statistical Computing; R Foundation for Statistical Computing: Vienna, Austria, 2018; Available online: https://www.r-project.org (accessed on 2 March 2020).

76. QGIS Development Team. QGIS Geographic Information System; Open Source Geospatial Foundation Project: Chicago, IL, USA, 2019; Available online: https://www.qgis.org/fr/site (accessed on 2 March 2020).

77. Petrovsky, V.V. The problem of the species-width in poppies of Russian Arctic. Skr. Norske Vidensk. Akad. Oslo 1999, 38, 243-259.

78. PAF. Panarctic Flora Project-Annotated Checklist of the Panarctic Flora-Vascular Plants. 2018. Available online: http://panarcticflora.org (accessed on 30 January 2020).

79. Solstad, H.; Elven, R.; Nordal, I. Are there too many species and subspecies in the Papaver radicatum complex? Skr. Norske Vidensk. Akad. Oslo 1999, 38, 281-294.

80. Paus, A. Late Weichselian vegetation, climate, and floral migration at Sandvikvatn, North Rogaland, south-western Norway. Boreas 1988, 17, 113-139. [CrossRef]

81. Dubiel, E.; Olech, M. Plant communities of NW Sörkapp Land (Spitsbergen). Zesz. Nauk. Uniw. Jagiellońskiego 1990, 21, 35-74.

82. Dubiel, E. Ecological observations on vascular plants in the NW Sörkapp Land (Spitsbergen). Zesz. Nauk. Uniw. Jagiellońskiego 1991, 22, 39-46.

83. Dubiel, E. Geobotanical problems of NW Sörkapp Land (Spitsbergen). Zesz. Nauk. Uniw. Jagiellońskiego 1991, 22, 15-38.

84. Thuiller, W.; Lavorel, S.; Araujo, M.B.; Sykes, M.T.; Prentice, I.C. Climate change threats to plant diversity in Europe. Proc. Natl. Acad. Sci. USA 2005, 102, 8245-8250. [CrossRef]

85. Guerrina, M.; Conti, E.; Minuto, L.; Casazza, G. Knowing the past to forecast the future: A case study on a relictual, endemic species of the SW Alps. Berardia Subacaulis Reg. Environ. Chang. 2016, 16, 1035-1045. [CrossRef]

86. Casazza, G.; Giordani, P.; Benesperi, R.; Foggi, B.; Viciani, D.; Filigheddu, R.; Farris, E.; Bagella, S.; Pisanu, S.; Mariotti, M.G. Climate change hastens the conservation urgency of range-restricted plant species in the central-northern Mediterranean region. Biol. Conserv. 2014, 179, 129-138. [CrossRef]

87. Lenoir, J.; Gégout, J.C.; Marquet, P.A.; de Ruffray, P.; Brisse, H. A significant upward shift in plant species optimum eleveation during the 20th century. Science 2008, 320, 1768-1771. [CrossRef]

88. Dulliger, S.; Gattringer, A.; Thuiller, W.; Moser, D.; Zimmermann, N.E.; Guisan, A.; Willner, W.; Plutzar, C.; Leitner, M.; Mang, T.; et al. Extinction debt of high-mountain plant under twenty-first-century climate change. Nat. Clim. Chang. 2012, 2, 619-622. [CrossRef]

89. Cotto, O.; Wessely, J.; Georges, D.; Klonner, G.; Schmid, M.; Dulliger, S.; Thuiller, W.; Guillaume, F. A dynamic eco-evolutionary model predicts slow response of alpine plants to climate warming. Nat. Commun. 2017, 8, 15399. [CrossRef] [PubMed]

90. Alexander, J.M.; Chalmandrier, L.; Lenoir, J.; Burgess, T.I.; Essl, F.; Haider, S.; Kueffer, C.; McDougall, K.; Milbau, A.; Nunez, M.A.; et al. Lags in the response of mountain plant communities to climate change. Glob. Chang. Biol. 2017, 24, 563-579. [CrossRef] [PubMed] 
91. Patsiou, T.S.; Conti, E.; Zimmermann, N.E.; Theodoridis, S.; Randin, C. Topo-climatic microrefugia explain the persistence of a rare endemic plant in the Alps during the last 21 millennia. Glob. Chang. Biol. 2014, 20, 2286-2300. [CrossRef] [PubMed]

92. Suchan, T.; Malicki, M.; Ronikier, M. Relict populations and Central European glacial refugia: The case of Rhododendron ferrugineum (Ericaceae). J. Biogeogr. 2019, 46, 392-404. [CrossRef]

93. Vittoz, P.; Randin, C.; Dutoit, A.; Bonnet, F.; Hegg, O. Low impact of climate change on subalpine grassland in the Swiss Northern Alps. Glob. Chang. Biol. 2009, 15, 209-220. [CrossRef]

94. Aubert, S. La flore du Mont Tendre en raccourci. Bull. Cercle Vaud. Bot. 1952, 2, 25-26.

95. Moret, J.-L. Les plantes introduites à la Valée de Joux. Bull. Cercle Vaud. Bot. 2008, 37, 95-105.

(C) 2020 by the authors. Licensee MDPI, Basel, Switzerland. This article is an open access article distributed under the terms and conditions of the Creative Commons Attribution (CC BY) license (http://creativecommons.org/licenses/by/4.0/). 